\title{
Isotopic ratios of carbonaceous materials incorporated in olivine crystals from the Hualalai Volcano, Hawaii - An approach to mantle carbon
}

\author{
Shuichi Watanabe, Kazunobu Mishima and Sadao Matsuo \\ Department of Chemistry, Tokyo Institute of Technology, O-okayama, Meguro-ku, Tokyo 152, Japan
}

(Received January 8, 1983: Accepted February 3, 1983)

\begin{abstract}
Carbon dioxide and graphitic carbon in olivine crystals from dunite nodules in the 1801 lava flow of the Hualalai Volcano, Hawaii were extracted by three methods, i.e., the pyrolysis under oxygen atmosphere, the ball-milling and the dissolution with hydrochloric acid. It is concluded that most of $\mathrm{CO}_{2}$ extracted by the oxidative pyrolysis was derived from fluid inclusions, by comparing the isotopic ratios of $\mathrm{CO}_{2}$ released by the oxidative pyrolysis and the ball-milling. Graphitic carbon was recovered from the evaporation residue after olivine crystals were dissolved in hydrochloric acid.

The averaged concentration of $\mathrm{CO}_{2}$ extracted by the oxidative pyrolysis was $0.87 \mu \mathrm{mole} / \mathrm{g}$ and $\delta^{13} \mathrm{C}$ value was $-3.2 \%$. These of graphitic carbon were $0.51 \mu \mathrm{mole} / \mathrm{g}$ and $-26.9 \%$, respectively, No appreciable amount of hydrogen-bearing species such as $\mathrm{H}_{2}, \mathrm{H}_{2} \mathrm{O}, \mathrm{CH}_{4}$, higher hydrocarbons and $\mathrm{H}_{2} \mathrm{~S}$ was detected in olivine crystals by both the oxidative pyrolysis and the ball-milling. Assuming all the extracted carbon is present in fluid inclusions in olivine crystals and the disproportionation reaction of $\mathrm{CO}\left(2 \mathrm{CO} \rightarrow \mathrm{CO}_{2}+\mathrm{C}\right)$ has occurred in inclusions, we conclude that the major carbon-bearing species in the mantle beneath the Hawaiian Islands are $\mathrm{CO}$ and $\mathrm{CO}_{2}$, and the $\mathrm{CO} / \mathrm{CO}_{2}$ ratio is estimated to be about 3 on the basis of the experimental data and that the $\delta^{13} \mathrm{C}$ value of the carbon in upper mantle below the Hawaiian Islands is around $-12 \%$. Some additional data on Japanese olivines suggest that the $\delta^{13} \mathrm{C}$ value of the mantle carbon may not be unique throughout the mantle.
\end{abstract}

\section{INTRODUCTION}

A number of studies have been attempted to determine the isotopic composition of the juvenile carbon. The $\delta^{13} \mathrm{C}$ values of -8 to $-5 \%$ found for carbonatite, diamond and carbonate in kimberlite have been believed to represent the juvenile or deep-seated carbon (HoEFs, 1978). Some diamonds, however, are much depleted in ${ }^{13} \mathrm{C}$ (e.g., SMIRNov, et al., 1979). DeINES (1980) could not find an adequate model that is compatible with the wide range of $\delta^{13} \mathrm{C}$ of diamonds. Low $\delta^{13} \mathrm{C}$ values have been found for reduced carbon in a variety of igneous rocks (e.g., CRAIG, 1953 and HoEFs, 1973). In particular, it is remarkable that reduced carbon in mafic and ultramafic rocks (FUEX and BAKER, 1973) and in Icelandic magmatic rocks (GALIMOV and GERASIMOVSKIY, 1978) have much lower $\delta^{13} \mathrm{C}$ values, -30 to
$-20 \%$, than that of the so-called juvenile carbon.

PINEAU et al. (1976) found that the $\delta^{13} \mathrm{C}$ value of $\mathrm{CO}_{2}$ obtained by crushing fresh basalt of the Mid-Atlantic Ocean Ridge was $-7.6 \%$, but that of $\mathrm{CO}_{2}$ released by stepwise heating after crushing was more depleted in ${ }^{13} \mathrm{C}$. They attributed the difference to the isotopic fractionation during the outgassing process. The $\delta^{13} \mathrm{C}$ value of $\mathrm{CO}_{2}$ in volcanic gases from the Afar area, Ethiopia is about $-6 \%$ (Allard, 1979) and is almost the same as that of the $\mathrm{CO}_{2}$ extracted by crushing the fresh MORB.

JUNGE et al. (1975) assumed the $\delta^{13} \mathrm{C}$ value of carbon in the upper part of the earth to be $-4.5 \%$ by the material balance of carbonate carbon $(0 \% 0)$ and organic carbon $(-25 \% 0)$ with the abundance ratio of four to one. HoEFs (1973) also estimated the mean $\delta^{13} \mathrm{C}$ value of the earth's crust and the upper mantle to be 
around $-7 \%$ on the basis of the material balance calculation of carbon in every possible resevoir.

The $\delta^{13} \mathrm{C}$ value of the juvenile carbon of the earth may be related to that of meteoritic carbon which is in the range from -11.6 to $-5.6 \%$ (SMITH and KAPLAN, 1970). However, the average $\delta^{13} \mathrm{C}$ value of the mantle carbon with a variety of possible chemical forms such as $\mathrm{CO}_{2}$, $\mathrm{CO}$, hydrocarbons, carbides, graphite, diamond and carbonates has not yet been adequately estimated. Especially, the vertical and lateral changes in the $\delta^{13} \mathrm{C}$ value of the total carbon in the mantle is of great interest in connection with the mantle heterogeneity.

In this study, we adopted the olivine crystals of the Hualalai Volcano, Hawaii in order to determine the amounts and $\delta^{13} \mathrm{C}$ values of carbon in different chemical forms. Based on the results obtained, $\delta^{13} \mathrm{C}$ value of the mantle carbon in a hot spot was estimated.

\section{EXPERIMENTAL}

\section{Samples and sample preparation Olivine} crystals used in this study were obtained from dunite nodules in 1801 lava flow of the Hualalai Volcano, Hawaii. The Hualalai olivine has been studied by a number of researchers and was concluded to be transported from the mantle with an abundance of fluid inclusions consisting mostly of $\mathrm{CO}_{2}$ (e.g., GREEN and RADCLIFFE, 1975).

Olivine crystals were hand-picked from dunite nodules crushed into the size of about 20 mesh. In order to avoid the contamination of carbon, we did not use heavy liquid to separate minerals. The collected crystals were treated with $6 \mathrm{~N} \mathrm{HCl}$ and $6 \mathrm{~N} \mathrm{HNO}_{3}$ to remove surface contaminants, and washed several times with distilled water in a ultrasonic bath. After drying at about $100^{\circ} \mathrm{C}$, the crystal grains were subjected to subsequent chemical treatments.

\section{Procedure of carbon extractions Major} chemical species of carbon included in olivine crystals have been know to be $\mathrm{CO}_{2}$ and graphitic or elemental carbon according to previous studies (e.g., ROEDDER, 1965, and FREUND et al., 1980). For the extraction of carbon-bearing species, three methods have been applied, i.e., pyrolysis in oxygen atmosphere, ball-milling, and dissolution with hydrochloric acid.

$\mathrm{CO}_{2}$ extracted by these methods was collected after purification in a MacLeod gauge modified for a small amount of $\mathrm{CO}_{2}$ to determine the amount of $\mathrm{CO}_{2}$. The ${ }^{13} \mathrm{C} /{ }^{12} \mathrm{C}$ ratio was determined by a mass spectrometer, MM602C. The ${ }^{13} \mathrm{C} /{ }^{12} \mathrm{C}$ ratio is presented by $\delta^{13} \mathrm{C}(\% 0)$ relative to the ${ }^{13} \mathrm{C} /{ }^{12} \mathrm{C}$ ratio of the Pee Dee Belemnite (PDB).

a) Oxidative pyrolysis This method was intended to extract total carbon in olivine crystals. The basic principle of this method is the oxidative destruction of the structure of olivine crystals under a designated oxygen partial pressure. The oxidation of $\mathrm{Fe}^{\mathrm{II}}$ in the fayalite component of olivine brings about partial destruction of the crystal lattice, and gases incorporated in the destructed area are released. In this process, even reduced form of carbon is expected to be recovered in the form of $\mathrm{CO}_{2}$.

Approximately three grams of the pretreated olivine crystals was placed in a clean quartz tube and heated up to $850^{\circ} \mathrm{C}$ using a resistance furnace in vacuum for about 20 hours. Some contaminants and volatiles contained in a small amount of glass attached to crystal grains, which could not be separated by hand-picking are expected to be removed in this step. Fluid inclusions in crystals did not decrepitate under this condition (RoEDDER, 1965).

The clean oxygen gas evolved from $\mathrm{CuO}$ at $1,000^{\circ} \mathrm{C}$ (SAKAI et al., 1976) was introduced into the reaction tube. In the oxygen atmosphere of about 100 Torr, olivine crystals were kept at $1,000^{\circ} \mathrm{C}$ for 20 to 24 hours.

The oxygen gas was then absorbed in $\mathrm{Cu}_{2} \mathrm{O}$ $\mathrm{CuO}$ at $700^{\circ} \mathrm{C}$ to reduce $\mathrm{p}_{\mathrm{O}_{2}}$ below $10^{-2}$ Torr, so that the collection of $\mathrm{CO}_{2}$ extracted from olivine crystals was facilitated. The extracted gases were composed of $\mathrm{CO}_{2}$ and $\mathrm{H}_{2} \mathrm{O}$. No $\mathrm{SO}_{2}$ and $\mathrm{SO}_{3}$ were detected mass spectrometrically 
in the gases. The $\mathrm{CO}_{2}$ was separated from $\mathrm{H}_{2} \mathrm{O}$ by passing the gases through a dry ice-alcohol trap several times.

\section{b) Ball-milling The purpose of this method} is to collect $\mathrm{CO}_{2}$ from the fluid inclusions and to compare its $\delta^{13} \mathrm{C}$ value with that of $\mathrm{CO}_{2}$ extracted by the oxidative pyrolysis to which a contribution of graphitic carbon is suspected.

A ball-mill designed by KITA (1981) was used in this study. The ball-mill consists of a Pyrex glass tube and an alumina ball.

About four grams of the pretreated olivine crystals was placed at the bottom of the tube with an alumina ball and evacuated at $300^{\circ} \mathrm{C}$ until detectable gas release stopped. The olivine crystals were then crushed by manual shaking of the mill for an hour at room temperature and the volatiles released were recovered while heating the mill externally at $300^{\circ} \mathrm{C}$. After $\mathrm{CO}_{2}$ was purified by trap works, its amount and ${ }^{13} \mathrm{C} /{ }^{12} \mathrm{C}$ ratio were measured.

c) Dissolution method The graphitic or non-volatile carbon in crystals was extracted exclusively by this method. One to two grams of olivine crystals was weighed in a quartz tube and pretreated by the same procedure as in the oxidative pyrolysis. $25 \mathrm{ml}$ of conc. hydrochloric acid was introduced by distillation in vacuum into the tube which contained olivine crystals. The tube was kept in a water bath at 70 to $80^{\circ} \mathrm{C}$ for 3 days. After dissolution, the solution was evaporated in vacuum at about $70^{\circ} \mathrm{C}$. In this step, gaseous carbon species derived from fluid inclusions and carbonate were removed together with $\mathrm{HCl}, \mathrm{H}_{2} \mathrm{O}$ and $\mathrm{H}_{2} \mathrm{~S}$ from sulfides, if any. The evaporation residue was preheated at $300^{\circ} \mathrm{C}$ for about 12 hours in vacuum to dryness and then oxidized at $1,000^{\circ} \mathrm{C}$ in the oxygen atmosphere of about 100 Torr for more than 6 hours to recover graphitic carbon in the form of $\mathrm{CO}_{2}$. These steps were performed without breaking the vacuum. The evolved $\mathrm{CO}_{2}$ was separated from other volatiles. $\mathrm{HCl}$ and $\mathrm{Cl}_{2}$ were produced by thermal decomposition of the residue during oxidation. The gas including $\mathrm{HCl}$ and $\mathrm{Cl}_{2}$ was circulated through $\mathrm{CuO}$ at $700^{\circ} \mathrm{C}$ to separate $\mathrm{HCl}$ and $\mathrm{Cl}_{2}$ from $\mathrm{CO}_{2}$. $\mathrm{HCl}$ and $\mathrm{Cl}_{2}$ were converted to $\mathrm{CuCl}_{2}$ with the evolution of $\mathrm{H}_{2} \mathrm{O}$ and $\mathrm{O}_{2}$ on the surface of $\mathrm{CuO}$ at $700^{\circ} \mathrm{C}$ and separated from $\mathrm{CO}_{2}$. Negligible amount of $\mathrm{CO}_{2}$ was recovered when $0.18 \mu$ mole of pure $\mathrm{HCl}$ gas was circulated through $\mathrm{CuO}$ at $700^{\circ} \mathrm{C}$. The amount and $\delta^{13} \mathrm{C}$ value of purified $\mathrm{CO}_{2}$ were measured.

\section{RESUlts AND Discussion}

The dissolution method The content and $\delta^{13} \mathrm{C}$ value of carbon extracted by the dissolution method are given in Table 2 . The graphitic carbon content ranged from 0.4 to $0.6 \mu \mathrm{mole} / \mathrm{g}$ and the $\delta^{13} \mathrm{C}$ value was in the range from -29 to $-26 \%$. The $\delta^{13} \mathrm{C}$ values are similar to those of the non-carbonate carbon of mafic and ultramafic rocks of -27 to $-22 \%$ found by FUEX and BAKER (1973) and those of reduced form of carbon in Icelandic magmatic rocks of -32.6 to $-24.5 \%$ given by GaLIMOV and GerasimovSKIY (1978). The average values of the content and $\delta^{13} \mathrm{C}$ of graphitic carbon were $0.51 \mu \mathrm{mole} / \mathrm{g}$ and $-26.9 \%$, respectively.

The oxidative pyrolysis As given in Table 2, the average values of the content and $\delta^{13} \mathrm{C}$ of $\mathrm{CO}_{2}$ recovered by the oxidative pyrolysis were $0.87 \mu \mathrm{mole} / \mathrm{g}$ and $-3.2 \%$, respectively.

The diffusion coefficient of $\mathrm{O}_{2}$ gas in forsterite, which is estimated by extrapolation of the result reported by REDDY et al. (1980), is $1.9 \times 10^{-18} \mathrm{~cm}^{2} / \mathrm{sec}$ in our experimental condition of $1,000^{\circ} \mathrm{C}$. YUND et al. (1981) estimated that the diffusion coefficinet of $\mathrm{O}_{2}$ in albite

Table 1. Result of carbon extraction by pure heating and oxidative pyrolysis of run No. 4

\begin{tabular}{cc}
\hline $\begin{array}{c}\text { Temperature } \\
\left({ }^{\circ} \mathrm{C}\right)\end{array}$ & $\begin{array}{c}\text { C content } \\
(\mu \mathrm{mole} / \mathrm{g})\end{array}$ \\
\hline $200-850$ & 0.27 \\
$850-1,000$ & 0.12 \\
$1,000-1,100$ & 0.04 \\
\hdashline $1,000^{*}$ & 0.67 \\
\hline
\end{tabular}

* In oxygen atmosphere about 100Torr. 
Table 2. Results of carbon extraction by the three methods

\begin{tabular}{|c|c|c|}
\hline Method & $\begin{array}{l}\text { C content } \\
(\mu \mathrm{mole} / \mathrm{g})\end{array}$ & $\begin{array}{c}{ }^{{ }^{13}} \mathrm{C}_{\mathrm{PDB}} \\
(\% 0)\end{array}$ \\
\hline \multicolumn{3}{|c|}{ Oxidative pyrolysis } \\
\hline No. 1 & 0.90 & -3.5 \\
\hline No. 2 & 0.95 & -2.6 \\
\hline No. 3 & 0.94 & -4.0 \\
\hline No. $4 *$ & 0.67 & -2.6 \\
\hline av. & 0.87 & -3.2 \\
\hline \multicolumn{3}{|l|}{ Ball-milling } \\
\hline No. 1 & 0.20 & -4.1 \\
\hline No. 2 & 0.18 & -5.5 \\
\hline \multicolumn{3}{|c|}{ Dissolution method } \\
\hline No. 1 & 0.54 & -25.8 \\
\hline No. 2 & 0.38 & -25.6 \\
\hline No. 3 & 0.50 & -27.3 \\
\hline No. 4 & 0.60 & -29.0 \\
\hline av. & 0.51 & -26.9 \\
\hline
\end{tabular}

* After stepwise heating.

along a dislocation core was five orders of magnitude greater than through the crystal lattice. Even if the diffusion coefficient of $\mathrm{O}_{2}$ in forsterite crystal of $2 \times 10^{-13} \mathrm{~cm}^{2} / \mathrm{sec}$ is assumed, the range of diffusion of $\mathrm{O}_{2}$ is only several $\mu \mathrm{m}$ in a week. The diffusion of $\mathrm{O}_{2}$ is so slow that the complete oxidation of $\mathrm{Fe}^{\mathrm{II}}$ in the crystal is impossible under our experimental condition.

The powder X-ray diffraction analysis also supports the incomplete oxidization. There was no remarkable difference in the diffraction patterns between the original and the treated olivine in oxygen atomsphere at $1,000^{\circ} \mathrm{C}$. Two minor differences, however, were detected, i.e., a weak diffraction due to hematite appeared and the diffraction pattern of the treated olivine shifted to that of pure forsterite. It is concluded by these observations that the crystal structure of olivine after oxidative pyrolysis was not drastically disturbed, becuase its lattice structure was retained, though a part of fayalite component was oxidized. Microscopic observation clearly indicated the oxidation of $\mathrm{Fe}^{\mathrm{II}}$. The actual size of a part which turned black by the formation of hematite was larger than the size

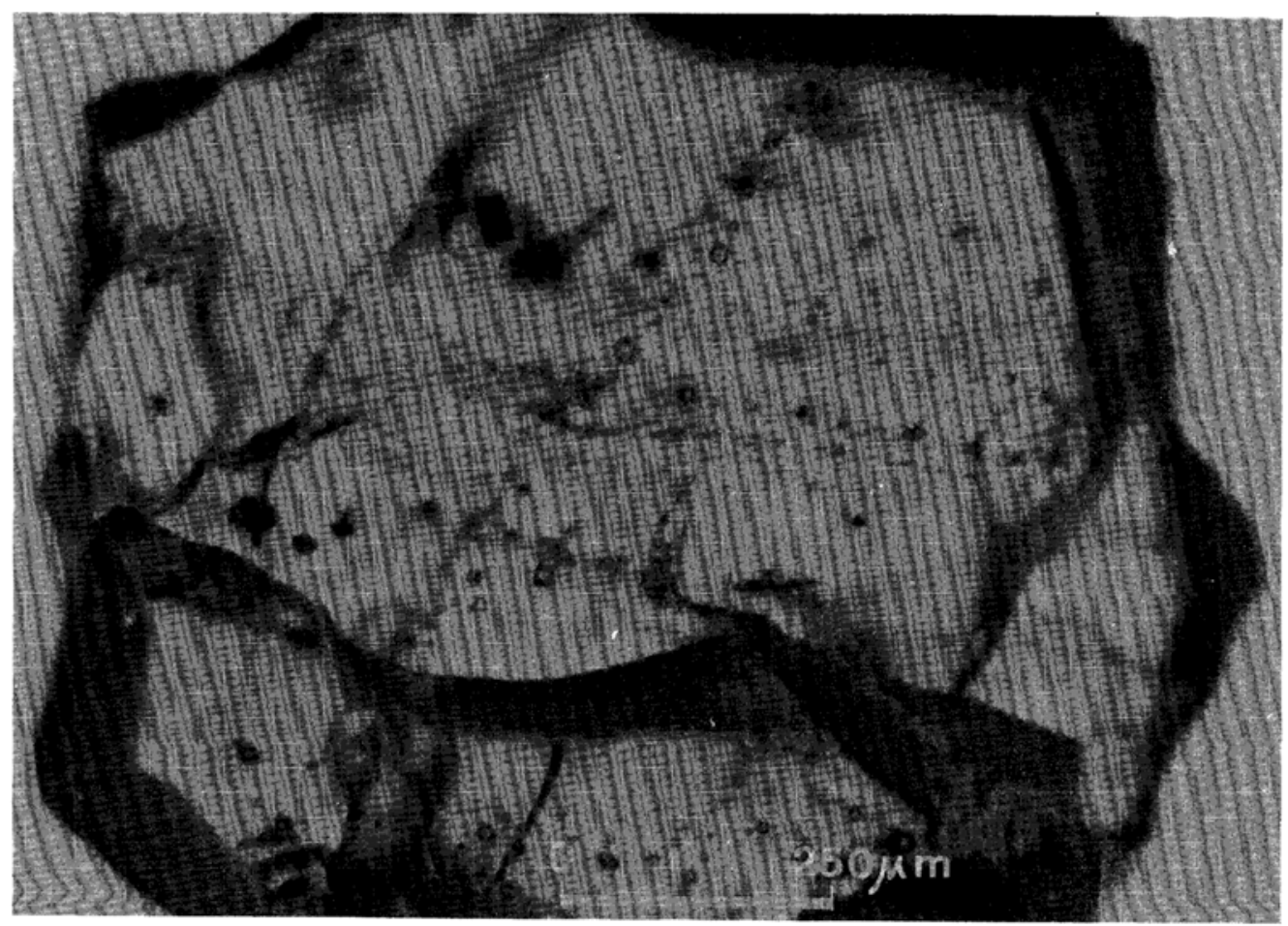

Fig. 1-a 
expected from the range of $\mathrm{O}_{2}$ diffusion.

It is conceivable, however, that oxidation takes place along dislocations or structural weakness in olivine crystals. As seen in Fig. 1-b and 1-c there are many cracks, channels and voids which connect several inclusions. The voids should have been formed by decrepitation of fluid inclusions through structural weakness caused by oxidation, so that gaseous components were more effectively extracted through these cracks and channels than in the case of ball-milling. Since the repeated oxidative pyrolysis of an identical sample gave negligible amount of $\mathrm{CO}_{2}$, we may conclude that the recovery of $\mathrm{CO}_{2}$ from fluid inclusion was complete.

Fluid inclusions in olivine crystals decrepitate above $1,200^{\circ} \mathrm{C}$ (RoEdDER, 1965). Some volatiles incorporated in basaltic glass can be released even below $1,000^{\circ} \mathrm{C}$ (DELANEY et al. 1978). As given in Table 1 , the amount of $\mathrm{CO}_{2}$ extracted in vacuum decreased with increasing temperature. This suggests that the $\mathrm{CO}_{2}$ thus collected can be derived mostly from surface contaminants of olivine crystals. The $\delta^{13} \mathrm{C}$ values of $\mathrm{CO}_{2}$ extracted from runs Nos. 1,2 and 3 in vacuum up to $850^{\circ} \mathrm{C}$ were centered at $-23 \%$, which also indicates that this $\mathrm{CO}_{2}$ was derived mostly from organic carbon on the surface of crystals and/or in the glassy part attached to the crystal.

The average $\delta^{13} \mathrm{C}$ value of $\mathrm{CO}_{2}$ obtained by the oxidative pyrolysis was $-3.2 \%$ (Table 2 ). This value is much higher than that of the carbon extracted by the dissolution method and is close to that of $\mathrm{CO}_{2}$ collected by the ballmilling to be mentioned in the next section (see Table 2). These results indicate that carbonbearing species extracted in the form of $\mathrm{CO}_{2}$ by the oxidative pyrolysis contain little graphitic carbon.

The gas pressure of inclusions in the Hualalai

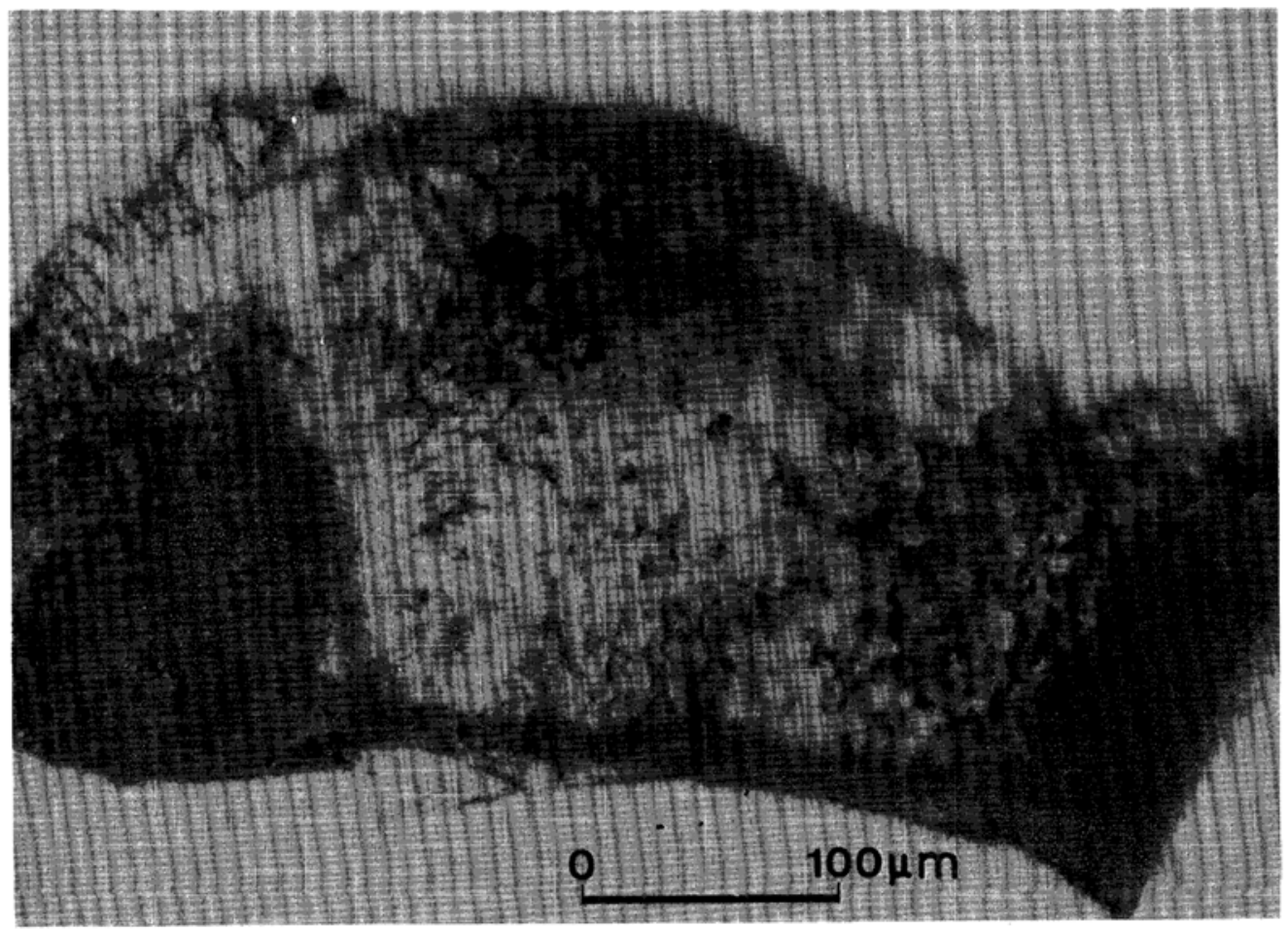

Fig. 1-b 
olivine crystals has been estimated by MURCK et al. (1978) to be $3.4 \mathrm{kbar}$ if entrapped at $1,200^{\circ} \mathrm{C}$. When the release of $\mathrm{CO}_{2}$ from inclusions is made by decrepitiation through structural weakness, as mentioned previously, a jetlike stream of $\mathrm{CO}_{2}$ is expected. After $\mathrm{CO}_{2}$ is released, $\mathrm{O}_{2}$ of 100 Torr penetrates through crooked channels into the interior of crystal grains. The penetration process of $\mathrm{O}_{2}$ may have been sluggish, so that the oxidation of graphitic carbon present in the crystal was not effectively made.

Water and hydrocarbons in fluid inclusions should have been recovered together with $\mathrm{CO}_{2}$ by this method. The amount of water extracted by this method, however, was almost the same as that of the blank run. As hydrogen in hydro- carbons was converted to water and collected together with the original water, our result indicates that fluid inclusion in the Hualalai olivine crystal contains neither water nor hydrocarbons in detectable amount.

The ball-milling The amount and $\delta^{13} \mathrm{C}$ values of $\mathrm{CO}_{2}$ released from fluid inclusions are given in Table 2. Since $\mathrm{CO}_{2}$ exists in fluid inclusions, it is worthy to compare its $\delta^{13} \mathrm{C}$ value with that extracted by the oxidative pyrolysis.

The $\delta^{13} \mathrm{C}$ values of $\mathrm{CO}_{2}$ extracted by the ball-milling are -4.1 and $-5.5 \%$ and lower by 1 to $2 \%$ as compared with those of the oxidative pyrolysis. It cannot be made clear whether or not this slight difference is due to isotopic heterogeneity of inclusions. This result,

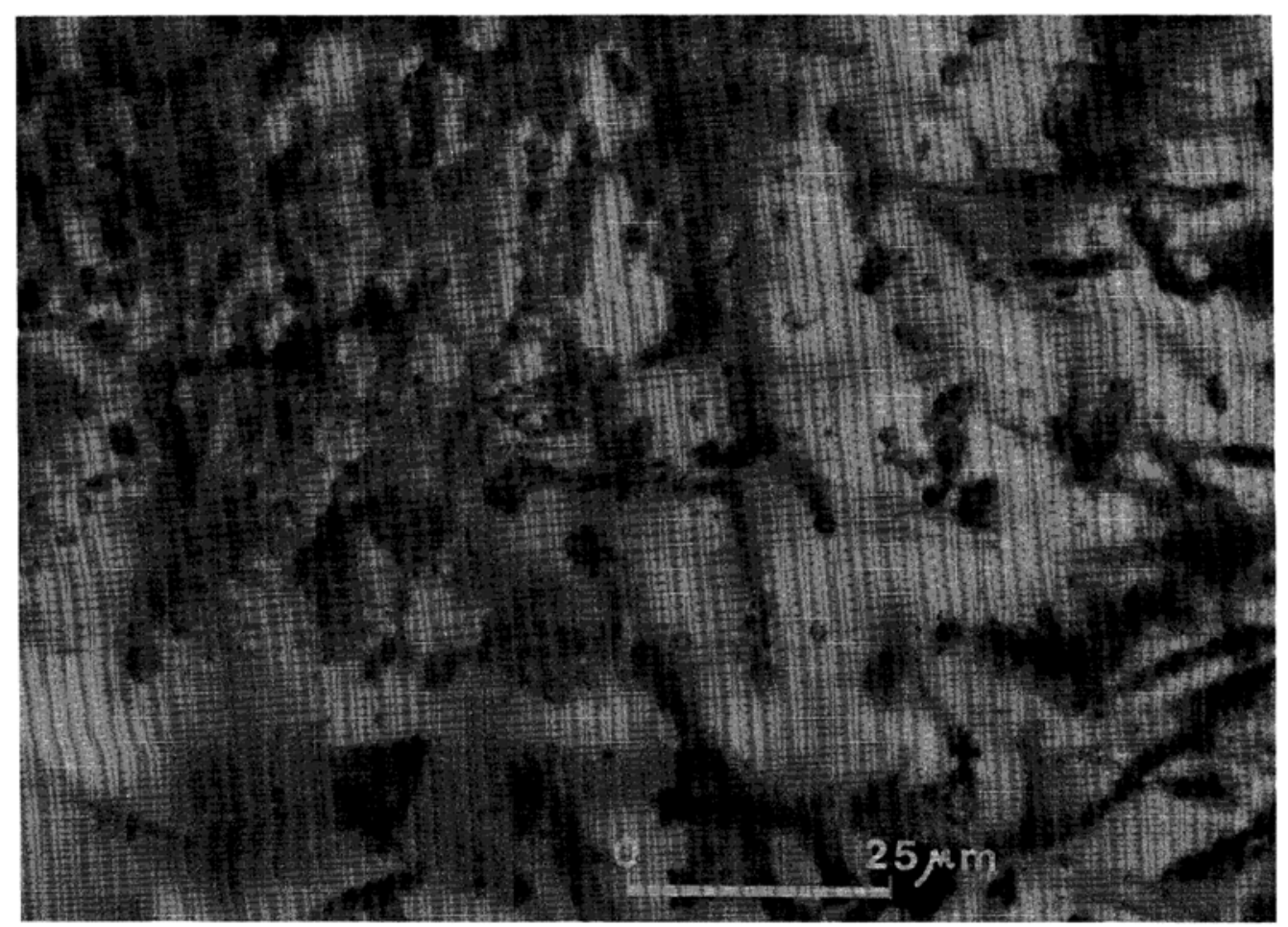

Fig. 1-c

Fig. 1. a) Photomicrograph of the original olivine crystal obtained from a dunite nodule in the Hualalai Volcano, Hawaii. Many inclusions are observed in the crystal.

b) Photomicrograph of an olivine crystal after oxidative pyrolysis. Many cracks and channels are formed with partial oxidation in the olivine crystal.

c) Channels and voids in an oxidized olivine crystal which connect several inclusions. 
however, indicates that most of the $\mathrm{CO}_{2}$ extracted by the oxidative pyrolysis should be derived from fluid inclusions.

A carbon-bearing species such as calcite decomposes on heating. The calcite formed at high temperature under isotopic exchange equilibrium with $\mathrm{CO}_{2}$ has about the same isotopic ratio or slightly depleted in ${ }^{13} \mathrm{C}$ as compared with gaseous $\mathrm{CO}_{2}$ (BotTINGA, 1969). If calcite re-equilibrates with $\mathrm{CO}_{2}$ at low temperature, calcite would be enriched in ${ }^{13} \mathrm{C}$. When $\mathrm{CO}_{2}$ from this calcite contributes to the $\mathrm{CO}_{2}$ extracted by the oxidative pyrolysis, the $\delta^{13} \mathrm{C}$ value of $\mathrm{CO}_{2}$ extracted by the ball-milling should be lower than that by the oxidative pyrolysis.

The $\mathrm{H}_{2} \mathrm{O} / \mathrm{CO}_{2}$ ratio obtained by the ballmilling was also too low to give a definite value for the Hualalai sample. It is evident that the Hualalai olivine has been crystallized under extremely water-deficient conditions.

The existence of graphitic carbon in fluid inclusions FreUND et al. (1980) suggested that atomic carbon can be retained in the lattice of olivine crystals on the basis of the study of synthetic forsterite and naturally occurring olivine crystals by a laser-induced mass spectrometry. On the other hand, MATHEZ and DELANEY (1981) proved the presence of carbonaceous materials in submarine basaltic glass and mantle-derived peridotite nodules in alkali basalt using electron microprobe techniques. Carbonaceous materials in peridotite nodules were detected in microcracks, grain boundaries and on the wall of fluid inclusions. They suggested that the carbonaceous materials consisted mostly of graphite and small amounts of organic matter.

Our observations by SIMS (Secondary Ion Mass Spectrometer) using $\mathrm{O}_{2}^{+}$beam as primary ions supported the existence of carbonaceous materials inside inclusions, because the more intense ion current at $\mathrm{M} / \mathrm{e}$ of $12\left(i_{12}\right)$ was detected in the area where the number density of inclusions was higher. The ion current of ${ }^{24} \mathrm{Mg}^{2+}$ overlaps that of ${ }^{12} \mathrm{C}^{+}$, so that we calculated $i_{12} \mathrm{C}^{+}$to be equal to $i_{12}$ (measured) $-i_{24} \mathrm{Mg}^{2+}$ on the assumption that $i_{24} \mathrm{Mg}^{+} / i_{25} \mathrm{Mg}^{+}=i_{24} \mathrm{Mg}^{2+} /$ $i_{25} \mathrm{Mg}^{2+} . \quad i_{12} \mathrm{C}^{+}$can be estimated by measuring $i_{12}, i_{12.5}, i_{24}$ and $i_{25}$. It has been proved that $\mathrm{CO}_{2}$ in fluid inclusions does not contribute to $i_{12}$ peak, even when an inclusion is broken by the primary ion beam.

\section{The existence of $\mathrm{CO}$ in the mantle The} existence of graphitic carbon in inclusions has been proposed first by ROEDDER (1965) and later by MATHEZ and Delaney (1981) as the product of disproportionation reaction of $\mathrm{CO}$, originally present in inclusions, $2 \mathrm{CO} \rightarrow \mathrm{C}+\mathrm{CO}_{2}$. If all the carbon obtained by the dissolution method (exclusively graphitic carbon) are the product from $\mathrm{CO}$, the original $\mathrm{CO} / \mathrm{CO}_{2}$ ratio when inclusions of the Hualalai olivine were formed can be estimated roughly to be 3 on the basis of the average values of $\mathrm{CO}_{2}$ and $\mathrm{C}$ contents (refer to Table 2). The equilibrium ratio of $\mathrm{CO} / \mathrm{CO}_{2}$ calculated thermodynamically is 4 under the condition of $1,200^{\circ} \mathrm{C}$ and $\mathrm{p}_{\mathrm{O}_{2}}$ of $10^{-12} \mathrm{~atm}$ which was measured directly by SATo (1978) for the Hualalai olivine. Considering the error and uncertainty involved in both calculations, the estimated $\mathrm{CO} / \mathrm{CO}_{2}$ ratio and the equilibrium ratio should be said to agree with each other. This result suggests that $\mathrm{CO}$ is one of the major gaseous components, among carbon-bearing species in the mantle. The possibility that the graphitic carbon is the most abundant species in the mantle, however, can not be ruled out from the thermodynamic point of view.

\section{Carbon isotopic composition in the mantle}

Since the Hualalai olivine crystals are concluded to have been originated from the mantle (GREEN and RADCLIFFE, 1975), the $\delta^{13} \mathrm{C}$ value of total carbon in the mantle beneath the Hawaiian Islands can be estimated to be $-12 \%$ on the basis of the data given in this study with the assumption that the mantle $\mathrm{CO} / \mathrm{CO}_{2}$ ratio has been retained in the inclusions when they were formed. This value was calculated by the isotopic mass balance of carbon extracted by the 
oxidative pyrolysis (averaged values, $0.87 \mu$ mole $\mathrm{CO}_{2} / \mathrm{g},-3.2 \%$ ) and by the dissolution method (averaged values, $0.51 \mu$ mole $\mathrm{C} / \mathrm{g},-26.9 \%$ ).

As mentioned earlier, the gas pressure of inclusions in the Hualalai olivine crystals was estimated to be $3.4 \mathrm{kbar}$ by MURCK et al. (1978). The depth assumed by the pressure of inclusions (about $11 \mathrm{~km}$ ) is still within the crust of that area (EATON and Murata, 1960), and the Hualalai nodules were deformed during passage to the surface (GREEN and RADCLIFFE, 1975). It is possible that the crustal carbon contamination to and loss of original carbon-bearing species from the inclusion occur during the ascending process. The crustal contamination, however, is inferred to have been small, because the pressure of inclusion should have been about $5 \mathrm{kbar}$ before the disproportionation of $\mathrm{CO}$ in the inclusion took place during the cooling process. This estimated pressure correpsonds to the boundary between the crust and the mantle underneath the Hawaii area. An extreme deficiency of water in fluid inclusions may indicate that the accumulation of the volatiles occurred in a relatively small and limited region in this particular area.

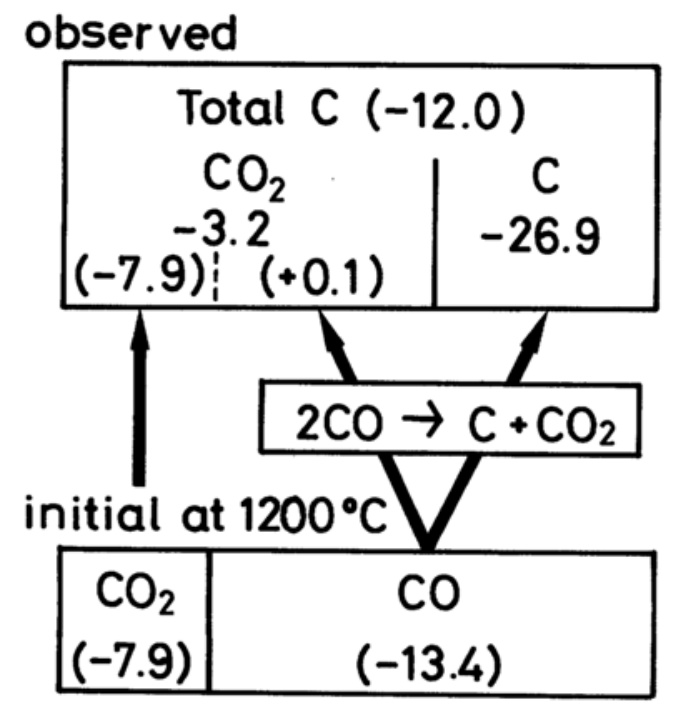

Fig. 2. Changes in amount and $\delta^{13} C$ of carbon-bearing species between the original mantle substance and present fluid inclusions. Figures in parentheses are the calculated value.
Our estimated $\delta^{13} \mathrm{C}$ value of carbon of in the mante $-12 \%$ is lower by about $5 \%$ than the $\delta^{13} \mathrm{C}$ value of the so-called juvenile carbon. The $\delta^{13} \mathrm{C}$ value of $\mathrm{CO}_{2}$ of volcanic gases from the lava lake of Aloi crater was approximately $-15 \%$ (FRIEDMAN and O'NeIL, 1971), which indicates that $\mathrm{CO}_{2}$ in the lava lake is fed with only slight contamination of crustal carbon.

Based on our results, we may estimate the $\delta^{13} \mathrm{C}$ values of $\mathrm{CO}_{2}$ and $\mathrm{CO}$ originally present in the mantle below the Hawaiian Islands. The results of calculation is schematically shown in Fig. 2. For this calculation, isotopic exchange equilibrium was assumed between $\mathrm{CO}$ and $\mathrm{CO}_{2}$ at $1,200^{\circ} \mathrm{C}$ when $\mathrm{CO}$ and $\mathrm{CO}_{2}$ were entrapped in inclusions, so that $\delta^{13} \mathrm{C}_{\mathrm{CO}_{2}}-\delta^{13} \mathrm{C}_{\mathrm{CO}}$ was taken to be $5.5 \%$ (RICHET et al., 1977). Since the $\delta^{13} \mathrm{C}$ value of the total carbon has been estimated to be $-12.0 \%$, those of the originally present $\mathrm{CO}$ and $\mathrm{CO}_{2}$ were calculated to be -13.4 and $-7.9 \%$ respectively. During the cooling process $\mathrm{CO}$ disproportionated into graphitic carbon and $\mathrm{CO}_{2}$. According to our calculation, no isotopic exchange equilibrium has been established between $\mathrm{CO}, \mathrm{CO}_{2}$ and graphitic carbon, because $\delta^{13} \mathrm{C}_{\mathrm{CO}_{2}}>\delta^{13} \mathrm{C}$ graphite $>\delta^{13} \mathrm{C}_{\mathrm{CO}}$ (BotringA, 1969 and Richet et al., $1977)$, if the isotopic exchange equilibrium was established.

No information on isotopic fractionation has been reported so far with respect to this disproportionation process. We can not go further to discuss the kinetic mechanism that controls the isotopic fractionations.

\section{CONCLUding Remarks}

The Hualalai olivine is peculiar in its extraordinarily abundant fluid inclusions consisting mostly of $\mathrm{CO}_{2}$. This was the major reason why we adopted the Hualalai olivine for the exploitation of technique to extract a variety of carbon from the mantle substance. Actually, most of olivines with different localities and occurrences we examined contain almost no detectable amount of fluid inclusions. A certain amount of volatiles including $\mathrm{H}_{2} \mathrm{O}$ has been 
Table 3. Results of carbon extraction from Japanese olivines

\begin{tabular}{|c|c|c|c|}
\hline Sample locality & Method & $\begin{array}{l}\text { C content } \\
(\mu \text { mole } / \mathrm{g})\end{array}$ & $\begin{array}{c}{ }^{\delta^{13}} \mathrm{CPDB}_{\mathrm{PD}} \\
(\% 0)\end{array}$ \\
\hline \multirow[t]{2}{*}{ Takashima } & $\begin{array}{c}\text { Oxidative } \\
\text { pyrolysis }\end{array}$ & 0.12 & -14.3 \\
\hline & Dissolution & 0.20 & -29.4 \\
\hline \multirow[t]{2}{*}{ Ichinomegata } & $\begin{array}{c}\text { Oxidative } \\
\text { pyrolysis }\end{array}$ & n.d. & - \\
\hline & Dissolution & 0.14 & -26.1 \\
\hline
\end{tabular}

extracted from Ichinomegata olivine in Akita Pref., Japan by Suzuoki et al. (1975). They concluded, however, that volatiles were derived mostly from glass inclusions in the olivine crystal. We have extracted a significant amount of $\mathrm{H}_{2} \mathrm{O}$ from orthopyroxene in the peridotite nodule from the same locality (to be published elsewhere). In this case, $\mathrm{H}_{2} \mathrm{O} / \mathrm{CO}_{2}$ ratio was quite high. The quite low $\mathrm{H}_{2} \mathrm{O} / \mathrm{CO}_{2}$ ratio found in the Hualalai olivine needs to be elucidated by the future study.

Some additional results on carbon extraction from Japanese olivines are given in Table 3. As seen in Table 3, the Ichinomegata olivine gave no detectable amount of $\mathrm{CO}_{2}$ by the oxidative pyrolysis. On the other hand, the graphitic carbon extracted by the dissolution method was measurable even for the $\delta^{13} \mathrm{C}$ value which was the same as that of the Hualalai olivine. The other olivine sample separated from the olivine nodule of alkali-olivine-basalt in Takashima, Kyushu, Japan was characterized by a low $\delta^{13} \mathrm{C}$ value of $\mathrm{CO}_{2}$ extracted by the oxidative pyrolysis, yet the $\delta^{13} \mathrm{C}$ value of graphitic carbon was within the range of graphitic carbon from the Hualali olivine.

Combining these results with that of the Hualalai, we may conclude that the mantle is not homogeneous with respect to the carbon isotopic composition. If this is the case, the recycling of carbon with different chemical forms and $\delta^{13} \mathrm{C}$ values in the upper part of the earth driven by global tectonics is expected to be realistic.

Acknowledgements-Special thanks are due to Dr. D. THOMAS of University of Hawaii who provided us with the Hualalai sample and informed us of the idea of oxidative pyrolysis. The authors are indebted to Prof. T. KATSURA and Dr. K. KITAYAMA of Tokyo Institute of Technology for their supports and encouragements throughout this study. We are grateful to Prof. J. OKANO and Dr. H. NISHIMURA who gave us permission to use their SIMS and valuable comments on the results of mass spectrometry. A number of comments and ideas given by Drs. I. FRIEDMAN, E. GALIMOV, M. JAVOY and R. KREULEN to this study in the occasion of 5th International Conference on Geochronology, Cosmochronology and Isotope Geology held in Japan, 1982 are highly appreciated. The authors' thanks are extended to Mr. A. ISHIDA for his assistance in the laboratory.

\section{REFERENCES}

Allard, P. (1979) ${ }^{13} \mathrm{C} /{ }^{12} \mathrm{C}$ and ${ }^{34} \mathrm{~S} /{ }^{32} \mathrm{~S}$ ratios in magmatic gases from ridge volcanism in Afar. Nature 282, 56-58.

BOTTINGA, Y. (1969) Calculated fractionation factors for carbon and hydrogen isotope exchange in the system calcite-carbon dioxide-graphite-methane-hydrogen-water vapor. Geochim. Cosmochim. Acta 33, 49-64.

CraIG, H. (1953) The geochemistry of the stable carbon isotopes. Geochim. Cosmochim. Acta 3, 53-92.

DEINES, P. (1980) The carbon isotopic composition of diamonds: relationship to diamond shape, color, occurrence and vapor composition. Geochim. Cosmochim. Acta 44, 943-961.

DelaneY, J. R., Muenow, D. W. and Graham, D. G. (1978) Abundance and distribution of water, carbon and sulfur in the glassy rims of submarine pillow basalts. Geochim. Cosmochim. Acta 42, 581594.

Eaton, J. P. and MURata, K. J. (1960) How volcanoes grow. Science 132, 925-938.

FREUND, F., KATHREIN, H., WENGRELER, H., KNOBEL, R. and HeINEN, H. J. (1980) Carbon in solid solution in forsterite - a key to the untractable nature of reduced carbon in terrestrial and cosmogenic rocks. Geochim. Cosmochim. Acta 44, 1319-1333.

FRIEDMAN, I. and O'NEIL, J. (1971) $\quad \mathrm{C}^{13}-\mathrm{C}^{12}$ ratios of $\mathrm{CO}_{2}$ from Hawaiian lava lake. U.S. Geological Survey Professional Ppaer 750, A126.

FUEX, A. N. and BAKER, D. R. (1973) Stable carbon isotopes in selected granitic, mafic, and ultramafic igneous rocks. Geochim. Cosmochim. Acta 37, 2509-2521.

GaLIMOV, E. M. and GeRASIMOVSKIY, V. I. (1978) 
Isotopic composition of carbon in Icelandic magmatic rocks. Geockhimiya 1978, 1615-1621.

GrEEN, H. W. and RADClifFE, S. V. (1975) Fluid precipitates in rocks from the earth's mantle. Geol. soc. Am. Bull. 86, 846-852.

HOEFS, J. (1973) Ein Beitrag zur Isotopengeochemie des Kohlenstoffs in magmatischen Gesteinen. Contrib. Mineral. Petrol. 41, 277-300.

HOEFS, J. (1978) Some peculiarities in the carbon isotope composition of "juvenile" carbon. In Stable isotope in the earth science, DSIR. Bull. 220, 181184.

JUNGe, C. E., SCHIDlowSKI, M., EICHMANN, R. and PIETREK, H. (1975) Model calculations for the terrestiral carbon cycle: carbon isotope geochemistry and evolution of photosynthetic oxygen. J. Geophys. Res. 80, 4542-4552.

KITA, I. (1981) A new type ball mill made of pyrex glass. Geochem. J. 15, 289-291.

MATHEZ, E. A. and Delaney, J. R. (1981) The nature and distribution of carbon in submarine basalts and peridotite nodules. Earth Planet. Sci. Lett. 56, 217-232.

MURCK, B. W., BURRUSS, R. C. and HOLLISTER, L. S. (1978) Phase equilibria in fluid inclusions in ultramafic xenoliths. Am. Mineral. 63, 40-46.

Pineau, F., JAVOY, M. and BotTinga, Y. (1976) ${ }^{13} \mathrm{C} /{ }^{12} \mathrm{C}$ ratios of rocks and inclusions in popping rocks of Mid-Atlantic Ridge and their bearing on the problem of isotopic composition of deep-seated carbon. Earth Planet. Sci. Lett. 29, 413-421.

REDDY, K. P. R., OH, S. M., MAJOR, L. D., JR. and COOPER, A. R. (1980) Oxygen diffusion in forsterite. J. Geophys. Res. 85, 322-326.

RicheT, P., BOTTINGA, Y. and JAVOY, M. (1977) A review of hydrogen carbon, nitrogen, oxygen, sulfur, and chlorine stable isotope fractionation among gaseous molecules. Ann. Rev. Earth Planet. Sci. 5, 65-110.

ROEDDER, E. (1965) Liquid $\mathrm{CO}_{2}$ inclusions in olivine-bearing nodules and phenocrysts from basalts. Am. Mineral. 50, 1746-1782.

SAKaI, H., Smith, J. W. Kaplan, I. R. and PetrowSKI, C. (1976) Micro-determinations of C, N, S, $\mathrm{H}, \mathrm{He}$, metallic $\mathrm{Fe}, \delta^{13} \mathrm{C}, \delta^{15} \mathrm{~N}$ and $\delta^{34} \mathrm{~S}$ in geologic samples. Geochem. J. 10, 85-96.

SATO, M. (1978) Oxygen fugacity of basaltic magmas and the role of gas-forming elements. Geophys. Res. Lett. 5, 447-449.

SMIRNOV, G. I., MOFOLO, M. M., LEROTHOLI, P. M., KAMINSKY, F. V., GALIMOV, E. M. and IVANOVSKAYA, I. N. (1979) Isotopically light carbon in diamonds from some kimberlite pipes in Lesotho. Nature 278, 630.

SMITH, J. W. and KAPLAN, I. R. (1970) Endogeneous carbon in carbonaceous meteorites. Science 167, 1367-1370.

SUZUOKI, T., KuRoda, Y. and Matsuo, S. (1975) Hydrogen extraction from silicate minerals by sodium carbonate fusion and its application to deuterium analyses of fluid inclusions in some olivines. Geochem. J. 9, 107-111.

YUND, R. A., SMITH, B. M. and Tullis, J. (1981) Dislocation-assisted diffusion of oxygen in albite. Phys. Chem. Minerals 7, 185-189. 